\title{
Microstructure and mineralogy of lightweight aggregates manufactured from mining and industrial wastes
}

\author{
B. González-Corrochano ${ }^{a}$, J. Alonso-Azcárate ${ }^{\mathrm{a}, *}$, M. Rodas ${ }^{\mathrm{b}}$, J.F. Barrenechea ${ }^{\mathrm{b}}$, F.J. Luque ${ }^{\mathrm{b}}$ \\ ${ }^{a}$ Department of Chemistry-Physics, School of Environmental Sciences, University of Castilia-La Mancha, Avenida Carlos III, s/n, 45071 Toledo, Spain \\ ${ }^{b}$ Department of Crystallography and Mineralogy, School of Geological Sciences, Complutense University of Madrid, Ciudad Universitaria, 28040 Madrid, Spain
}

Keywords:

Lightweight aggregate

Microstructure

Mineralogy

Washing aggregate sludge

Sewage sludge

Clay-rich sediment

\begin{abstract}
A B S T R A C T
The microstructure and mineralogy of lightweight aggregates manufactured with washing aggregate sludge, sewage sludge and a clay-rich sediment have been studied. The mineralogical analysis revealed the neo-formation of plagioclase and pyroxene group minerals and a minor presence of gehlenite. Some relationships may be established: (i) heating temperature and dwell time affect the formation of new porosity; (ii) the disappearance of pyroxenes could produce changes in the density of the solid material in the lightweight aggregates; (iii) when an external glassy film is not present, water absorption values depend on the size and number of each type of pore.
\end{abstract}

\section{Introduction}

Lightweight aggregates (LWAs) can be used in a wide range of applications, such as: thermal and acoustic insulation, manufacturing of precast structural units and structural lightweight concrete, geotechnical applications, gardening and hydroponics [1-3]. The assigned application depends on all their physical and chemical properties. As noted by Cheeseman et al. [4], for most applications an individual LWA granule should have a combination of:

(i) a low density and a porous, sintered, strong ceramic core Particle densities of natural aggregates are typically between 2.4 and $2.8 \mathrm{~g} / \mathrm{cm}^{3}$, while LWA densities range from 0.8 to $2.0 \mathrm{~g} / \mathrm{cm}^{3}$. Therefore, lightweight concrete, lightweight blocks and other lightweight construction materials can be manufactured with them. Additional benefits, such as higher thermal insulation and thermal inertia, are provided by the lower particle density [5].

Abbreviations: LWA, lightweight aggregate; W, washing aggregate sludge; SS, sewage sludge; $C$, clay-rich sediment; $\mathrm{WA}_{24 \mathrm{~h}}, 24 \mathrm{~h}$ water absorption; $\mathrm{BI}$, Bloating index; $S$, compressive strength; $\rho_{b}$, bulk density; $\rho_{d}$, dry particle density; BM, bulk mineralogy; LOI, loss on ignition; TG-DTA, thermogravimetry-differential thermal analysis; Qtz, quartz; Plg, plagioclases; Geh, gehlenite; Prx, piroxenes; $T_{\text {heating, }}$ temperature of heating; n.d., not determined. (ii) a dense, continuous external surface, in order to avoid water absorption, since the mechanical properties of lightweight concrete are significantly influenced by it [6]. The water absorption of lightweight aggregates is usually higher than that of normal aggregates. This high absorption rate can easily produce micro-cracking in the aggregate/cement interface during the early hydration stage [7].

(iii) a near-spheroid shape, in order to improve the properties of fresh concrete.

In turn, it has been reported [8] that important ceramic properties, such as density and water absorption, are intrinsically correlated with the pore system. Therefore, in order to better understand the relationship between the structure and the properties of lightweight aggregates, as well as the possible behavior of the aggregates in the concrete, it is necessary to investigate their structure (internal and external).

The available literature dealing with the microstructure of LWAs and its relationship to the properties of the final product is relatively scant, although LWA production has been studied both theoretically and practically $[9,10]$. The water absorption characteristics of aggregates made from sintered fly ash were investigated by Swamy and Lambert [11]. They also studied their pore structure and their bonding to the cement paste.

Bremner and Newman [12] observed, using scanning electron microscopy (SEM), that the internal microstructure of various types of lightweight aggregates was very similar, even when different raw materials and manufacturing methods were employed. 
A clear example of the relationship between microstructureproperties of LWAs is provided by Wasserman and Bentur [13], who modified the structure of LWAs using four types of heat treatment and one type of polymer treatment to obtain aggregates with different absorptions, strengths and pozzolanic activity. They also induced mineralogical changes in the aggregates with these treatments.

This work is the second part of a broader research project. The first part has been previously published [14]. Here, we describe the microstructure and the mineralogy of various artificial lightweight aggregates produced by the pelletizing and sintering of washing aggregate sludge $(W)$, sewage sludge $(S S)$ and a clay-rich sediment $(C)$. The raw material composition, heating temperature and dwell time effects on the microstructure and mineralogy of the studied LWAs are evaluated. In turn, the influence of these characteristics on the bloating index (BI), density, water absorption $\left(\mathrm{WA}_{24 \mathrm{~h}}\right)$ and compressive strength $(S)$ values, reported in the previous paper, are analyzed.

\section{Materials and methods}

Eight types of LWAs from a previous work [14], with four different initial compositions, were selected for the study of their microstructure and mineralogical composition. Aggregates of type W75525 (Table 1) were manufactured using a mixture of W:SS with a proportion of 75:25 (\% wt), whereas aggregates W50550 and W25575 presented a composition of 50:50 (\% wt) and 25:75 (\% wt), respectively. $W$ and $C$ were the raw materials for type $W 50 C 50$, with a $W: C$ ratio of $50: 50(\%$ wt). The mixtures were milled, a controlled amount of water was sprayed and they were kneaded and extruded. Cylinders of $1.5 \mathrm{~cm}$ of length were cut and rolled by hand. LWAs were firing in a rotary kiln in groups of 25 pellets. The heating temperatures ( $T_{\text {heating }}$ ) were $1150{ }^{\circ} \mathrm{C}, 1175^{\circ} \mathrm{C}, 1200^{\circ} \mathrm{C}$ and $1225^{\circ} \mathrm{C}$ for dwell times of 10 and 15 min $[14]$.

The characterization of the raw materials, mixtures and the physical properties of the LWAs were reported in detail in González-Corrochano et al. [14]. The main constituents of the $W$ and the $C$ were silica and alumina oxides (Table 2). Calcium oxide was also important in $W$, due to the presence of carbonate minerals in the sample. The $\mathrm{SiO}_{2}, \mathrm{Al}_{2} \mathrm{O}_{3}$ and $\mathrm{FeO}+\mathrm{Fe}_{2} \mathrm{O}_{3}$ contents mainly corresponded to quartz and phyllosilicates (illite, kaolinite and smectite) present in both samples. $\mathrm{Na}_{2} \mathrm{O}$ and $\mathrm{K}_{2} \mathrm{O}$ contents were mainly attributed to the interlayer cations of clay minerals and to feldspars [15]. In the SS, the main compound is $\mathrm{Al}_{2} \mathrm{O}_{3}$ (Table 2) along with amorphous compounds and/or organic matter [14]. Mixtures W75525 and W50C50 have a chemical composition located within the "bloating area" of the $\mathrm{SiO}_{2}-\mathrm{Al}_{2} \mathrm{O}_{3}$ - fluxing elements diagram [16].

Bloating Index (BI) expresses the volume change after firing of LWAs and it was determined following the equation: $B I=100 \times\left(d_{2}-d_{1}\right) / d_{1}$, where $d_{1}$ and $d_{2}$ are the diameters of pellets before and after firing respectively [15]. Dry particle density $\left(\rho_{d}\right)$ is the relationship between the mass of a sample of aggregates dried in an oven and the volume these aggregates occupy in water, including the watertight internal pores and the available pores to water [17]. $\rho_{d}$ and $W_{A_{24}}$ were determined using the procedure described by Norm UNE-EN 1097-6 [17]. Compressive strength is given as [18]: $S=(2.8 P c) /\left(\pi X^{2}\right)$, where $P c$ is the fracture load occurring rupture and $X$ is the distance between loading points. Tests of $\mathrm{BI}, \rho_{d}, \mathrm{WA}_{24 \mathrm{~h}}$ and $S$ were carried out on samples of 25 granules.

The selection criteria used to study the microstructure of the different types of LWAs were as follows (according to the results obtained by González-Corrochano et al. [14]):

- Sample $W 25575$, heated at $1150^{\circ} \mathrm{C}$ for a dwell time of $10 \mathrm{~min}$ (W25575-1150$10)$ : this is the LWA with $W$ and SS which has the highest water absorption and the lowest compressive strength values (Table 1 ).

- Samples $W 75525$ and $W 50550$, heated at $1150^{\circ} \mathrm{C}$ for $10 \mathrm{~min}(W 75525-1150-10$ and $W 50550-1150-10$, respectively): to compare them to sample W25575$1150-10$ and, thus, determine the influence of the proportion of $W$ and SS on the microstructure and mineralogy of the LWAs.

- Samples $W 75525$, heated at $1150^{\circ} \mathrm{C}$ for $15 \mathrm{~min}$ (W75525-1150-15) and $W 75525$, heated at $1225^{\circ} \mathrm{C}$ for $15 \mathrm{~min}$ (W75S25-1225-15): to compare them to sample W75525-1150-10 and evaluate the influence of the heating temperature and dwell time on the microstructure and mineralogy of the LWAs.

- Sample $W 50 C 50$, heated at $1150^{\circ} \mathrm{C}$ for $10 \mathrm{~min}(W 50 C 50-1150-10)$ : this is the LWA with $W$ and $C$ which has the highest water absorption and the lowest compressive strength values (Table 1 ).

- Sample W50C50, heated at $1150^{\circ} \mathrm{C}$ for $15 \mathrm{~min}$ (W50C50-1150-15) and at $1200^{\circ} \mathrm{C}$ for $15 \mathrm{~min}$ (W50C50-1200-15): to compare them with sample W50C50-1150-10 and determinate the influence of the temperature and the time on the microstructure and mineralogy of the LWAs.
The bulk density $\left(\rho_{b}\right)$ and dry particle density $\left(\rho_{d}\right)$ values of the aggregates studied were less than $1.20 \mathrm{~g} / \mathrm{cm}^{3}$ and $2.0 \mathrm{~g} / \mathrm{cm}^{3}$, respectively [14] so all these artificial aggregates were classified as lightweight aggregates according to UNE-EN 13055-1 [19].

Scanning electron microscopy (SEM), electron microprobe analyses (EMPA) and $X$-ray diffraction (XRD) studies were carried out in order to identify possible reasons for the variation in the properties of the LWAs. For each LWA type, granules with the most typical size and surface characteristics were chosen.

A scanning electron microscope (JSM-6400), connected to an energy-dispersive X-ray (EDX) analyzer, was used to examine the microstructure of gold-coated fracture surfaces of the LWAs (Table 1 ). They had been previously divided into two halves using a Nannetti ${ }^{\oplus}$ FM 96 press. One of them was glued onto a $\mathrm{Cu} / \mathrm{Zn}$ stub with colloidal silver and gold-coated. Thus, qualitative information about the heterogeneity of the pore system and semi-quantitative chemical analyses were obtained.

The EDX spectra showed only a semi-quantitative chemical analysis; therefore, additional tests were necessary. Electron microprobe analyses were performed on a JEOL JXA-8900 M WD/ED equipment. The lightweight aggregates (Table 1) were cut and embedded in an epoxy resin under vacuum conditions and the resulting slabs were polished and carbon-coated. All the analyses were performed with an accelerating voltage of $15 \mathrm{kV}$ and a spot size of $1 \mu \mathrm{m}$. Back-scattered electron microscope (BSEM) images were taken during the microprobe study, which provided textural information.

The bulk mineralogy (BM) was obtained by X-ray diffraction (XRD) after grinding and homogenization of the samples (three entire pellets of each type) to $<53 \mu \mathrm{m}$. Random-oriented powders were examined on an X'Pert Pro diffractometer, using $\mathrm{Cu} \mathrm{K} \alpha$ radiation and operating at $45 \mathrm{kV} / 40 \mathrm{~mA}$. All the XRD data were collected with a slit system (soller-mask-divergence-anti-scatter slits) of 0.04 rad$10 \mathrm{~mm}-1 / 8^{\circ}-1 / 4^{\circ}$, a step size of $0.01^{\circ}(2 \theta)$ and a time per step of $40 \mathrm{~s}$ (scan speed of $0.05 \%$ )

\section{Results and discussion}

Different types of relationships have been established between the parameters studied. These relationships can be classified into two groups:

1. Raw material composition, heating temperature and/or dwell time effects on the microstructure and/or mineralogy of the studied LWAs.

2. Microstructure and/or mineralogy effects on the physical properties of the studied LWAs.

\subsection{Relationship between raw material composition/heating temperature/dwell time - microstructure/mineralogy}

\subsubsection{Raw material composition/heating temperature/dwell time relationship with particle shape and surface texture}

The shape and surface texture of the aggregates have an influence on the properties of concrete [20].

Fig. 1 shows the apparent shape of granules before and after sintering. On the basis of visual inspection, the studied LWAs do not differ in particle shape, but they do differ in surface texture. All the types are rounded and sub-spherical in shape, which indicates that expansion, in the LWAs where it has taken place, has not been sudden enough to cause external fissures and cracks. This particle shape would result in a decrease in concrete production costs, because elongated and/or angular particles require more cement paste than rounded particles to produce workable concrete mixtures. In addition, the tendency to form water films next to the aggregate surface (bleeding) is higher in elongated and flat particles than in rounded ones. Bleeding produces a weakening of the interfacial transition zone, the region between aggregates and the hydrated cement paste, thereby indirectly affecting the concrete strength [20].

The surface texture is smoother in LWAs with $C$ than in LWAs with SS, and becomes rougher as the proportion of SS increases. The flexural strength of concrete can be affected by this factor. The physical bond between the cement paste and the aggregate may increase when the aggregate surface is very rough [21]. This 
Table 1

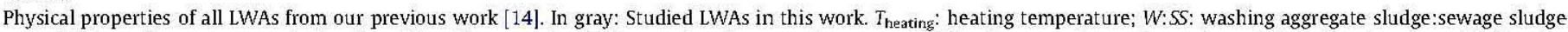

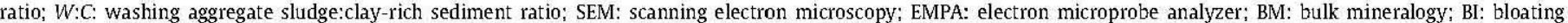
index $(\%) ; \rho_{d}$ : dry particle density $\left(\mathrm{g} / \mathrm{cm}^{3}\right)$; WA $24 \mathrm{~h}$ : water absorption after $24 \mathrm{~h}(\%) ; S$ : compressive strength (MPa); n.d: not determined.

\begin{tabular}{|c|c|c|c|c|c|c|c|c|}
\hline \multirow{2}{*}{$\begin{array}{l}T_{\text {heating }}\left({ }^{\circ} \mathrm{C}\right) \\
\text { Time (min) } \\
\text { Composition }\end{array}$} & \multicolumn{2}{|l|}{1150} & \multicolumn{2}{|l|}{1175} & \multicolumn{2}{|l|}{1200} & \multicolumn{2}{|l|}{1225} \\
\hline & 10 & 15 & 10 & 15 & 10 & 15 & 10 & 15 \\
\hline $\begin{array}{l}\text { W75S25 } \\
(W: S S \\
75: 25)\end{array}$ & $\begin{array}{l}\text { SEM } \\
\text { EMPA } \\
\text { BM } \\
\text { BI }=-2.39 \\
\rho_{d}=1.34 \\
W A_{24 h}=33.64 \\
S=3.07\end{array}$ & $\begin{array}{l}\text { BM } \\
\text { BI }=-2.15 \\
\rho_{d}=1.24 \\
W A_{24 h}=38.76 \\
S=2.78\end{array}$ & $\begin{array}{l}\mathrm{BI}=-4.60 \\
\rho_{d}=1.26 \\
W A_{24 \mathrm{~h}}=39.41 \\
S=3.34\end{array}$ & $\begin{array}{l}\mathrm{BI}=-4.03 \\
\rho_{d}=1.27 \\
W A_{24 h}=34.5 \\
S=3.5\end{array}$ & $\begin{array}{l}B I=-9.17 \\
\rho_{d}=1.25 \\
W A_{24 h}=39.20 \\
S=4.64\end{array}$ & $\begin{array}{l}\mathrm{BI}=-9.87 \\
\rho_{d}=1.35 \\
W A_{24 \mathrm{~h}}=32.46 \\
S=4.78\end{array}$ & $\begin{array}{l}\mathrm{BI}=-14.65 \\
\rho_{d}=1.79 \\
W A_{24 \mathrm{~h}}=12.42 \\
S=12.9\end{array}$ & $\begin{array}{l}B M \\
B I=-17.26 \\
\rho_{d}=1.81 \\
W A_{24 h}=12.33 \\
S=13.31\end{array}$ \\
\hline $\begin{array}{l}\text { W50S50 } \\
(W: S S \\
50: 50)\end{array}$ & $\begin{array}{l}\text { SEM } \\
\text { EMPA } \\
\text { BM } \\
\text { BI }=-6.455 \\
\rho_{d}=1.03 \\
W A_{24 h}=57.79 \\
S=1.45\end{array}$ & $\begin{array}{l}\mathrm{BI}=-5.51 \\
\rho_{d}=1.03 \\
W A_{24 h}=57.58 \\
S=1.54\end{array}$ & $\begin{array}{l}\mathrm{BI}=-6.00 \\
\rho_{d}=1.06 \\
W A_{24 \mathrm{~h}}=54.92 \\
S=1.66\end{array}$ & $\begin{array}{l}\mathrm{BI}=-6.35 \\
\rho_{d}=1.06 \\
W A_{24 h}=54.72 \\
S=1.6\end{array}$ & $\begin{array}{l}\mathrm{BI}=-7.61 \\
\rho_{\mathrm{d}}=1.04 \\
W A_{24 \mathrm{~h}}=56.44 \\
S=1.43\end{array}$ & $\begin{array}{l}\mathrm{Bl}=-7.03 \\
\rho_{d}=1.05 \\
W A_{24 \mathrm{~h}}=54.30 \\
S=1.54\end{array}$ & $\begin{array}{l}\mathrm{BI}=-6.55 \\
\rho_{d}=1.08 \\
W A_{24 \mathrm{~h}}=52.56 \\
S=1.56\end{array}$ & $\begin{array}{l}\mathrm{BI}=-8.32 \\
\rho_{\mathrm{d}}=1.08 \\
W A_{24 \mathrm{~h}}=52.05 \\
S=1.41\end{array}$ \\
\hline $\begin{array}{l}W 25 S 75 \\
(W: S S \\
25: 75)\end{array}$ & $\begin{array}{l}\text { SEM } \\
\mathrm{BM} \\
\mathrm{BI}=-12.042 \\
\rho_{d}=0.90 \\
W A_{24 \mathrm{~h}}=70.14 \\
S=0.5\end{array}$ & $\begin{array}{l}\mathrm{BI}=-11.53 \\
\rho_{d}=0.91 \\
W A_{24 h}=69.56 \\
S=0.77\end{array}$ & $\begin{array}{l}\mathrm{BI}=-12.95 \\
\rho_{d}=0.96 \\
W A_{24 \mathrm{~h}}=64.69 \\
S=0.93\end{array}$ & $\begin{array}{l}\mathrm{BI}=-12.70 \\
\rho_{d}=0.98 \\
W A_{24 \mathrm{~h}}=63.14 \\
S=0.91\end{array}$ & $\begin{array}{l}\mathrm{BI}=-14.57 \\
\rho_{\mathrm{d}}=0.95 \\
W A_{24 \mathrm{~h}}=65.19 \\
S=0.91\end{array}$ & $\begin{array}{l}\mathrm{BI}=-15.33 \\
\rho_{d}=0.96 \\
W A_{24 h}=64.27 \\
S=0.84\end{array}$ & $\begin{array}{l}\mathrm{BI}=-15.89 \\
\rho_{d}=1.03 \\
W A_{24 \mathrm{~h}}=60.04 \\
S=1.08\end{array}$ & $\begin{array}{l}\text { BI }=-18.39 \\
\rho_{d}=1.05 \\
W A_{24 h}=57.05 \\
S=1.22\end{array}$ \\
\hline $\begin{array}{l}\text { W50C50 } \\
\text { (W:C }\end{array}$ & $\begin{array}{l}\text { SEM } \\
\text { EMPA }\end{array}$ & & & & 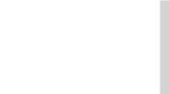 & $\begin{array}{l}\text { SEM } \\
\text { EMPA }\end{array}$ & $\begin{array}{l}\text { These LWAS co } \\
\text { adhered to the }\end{array}$ & $\begin{array}{l}\text { e fired because they } \\
\text { he rotary kiln [14] }\end{array}$ \\
\hline $50: 50)$ & $\begin{array}{l}\mathrm{BM} \\
\mathrm{BI}=-2.49 \\
\rho_{d}=1.88 \\
W A_{24 h}=8.45 \\
S=12.55\end{array}$ & $\begin{array}{l}\mathrm{BM} \\
\mathrm{BI}=-2.57 \\
\rho_{d}=1.88 \\
W A_{24 h}=8.44 \\
S=\mathrm{n}^{\mathrm{d}} \mathrm{d}^{\mathrm{a}}\end{array}$ & $\begin{array}{l}\mathrm{BI}=-2.89 \\
\rho_{d}=1.92 \\
W A_{2 A h}=6.6 \\
S=n . d^{a}\end{array}$ & $\begin{array}{l}\mathrm{BI}=-2.85 \\
\rho_{d}=1.97 \\
W A_{24 h}=3.48 \\
S=n . d^{a}\end{array}$ & $\begin{array}{l}\mathrm{BI}=2.46 \\
\rho_{\mathrm{d}}=1.88 \\
\mathrm{WA}_{24 \mathrm{~h}}=2.88 \\
S=\mathrm{n} \cdot \mathrm{d}^{\mathrm{a}}\end{array}$ & $\begin{array}{l}\mathrm{BM} \\
\mathrm{Bl}=4.26 \\
\rho_{d}=1.78 \\
W A_{24 h}=2.05 \\
S=\mathrm{n}_{.} \mathrm{d}^{2}\end{array}$ & & \\
\hline
\end{tabular}

a Values higher than $12.60 \mathrm{MPa}[14]$

Table 2

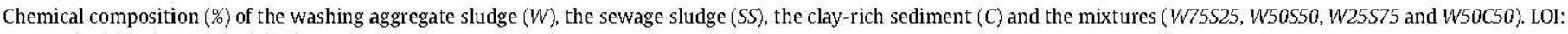
Loss on ignition $\left(\right.$ at $\left.1000^{\circ} \mathrm{C}\right)[14]$.

\begin{tabular}{|c|c|c|c|c|c|c|c|c|c|c|c|}
\hline Samples & $\mathrm{SiO}_{2}$ & $\mathrm{Al}_{2} \mathrm{O}_{3}$ & $\mathrm{FeO}$ & $\mathrm{Fe}_{2} \mathrm{O}_{3}$ & $\mathrm{CaO}$ & $\mathrm{MgO}$ & $\mathrm{K}_{2} \mathrm{O}$ & $\mathrm{Na}_{2} \mathrm{O}$ & $\mathrm{SO}_{3}$ & $\mathrm{TiO}_{2}$ & LOI \\
\hline$W$ & 53.59 & 10.48 & 1.34 & 1.49 & 13.03 & 1.74 & 2.51 & 0.81 & 0.02 & 0.44 & 15.72 \\
\hline SS & 14.84 & 38.52 & 0.73 & 0.81 & 3.57 & 0.93 & 0.64 & 0.58 & 0.18 & 0.13 & 51.19 \\
\hline C & 53.11 & 19.09 & 3.17 & 3.52 & 0.57 & 4.50 & 4.07 & 0.79 & 0.00 & 0.86 & 7.58 \\
\hline W75\$25 & 43.90 & 17.49 & 1.19 & 1.32 & 10.67 & 1.54 & 2.05 & 0.75 & 0.06 & 0.36 & 24.39 \\
\hline W50550 & 34.22 & 24.50 & 1.04 & 1.15 & 8.30 & 1.34 & 1.58 & 0.70 & 0.10 & 0.28 & 33.73 \\
\hline W25S75 & 24.53 & 31.51 & 0.88 & 0.98 & 5.94 & 1.14 & 1.11 & 0.64 & 0.14 & 0.21 & 47.31 \\
\hline W50C50 & 53.35 & 14.79 & 2.25 & 2.50 & 6.80 & 3.12 & 3.29 & 0.80 & 0.01 & 0.65 & 12.68 \\
\hline
\end{tabular}

(a)

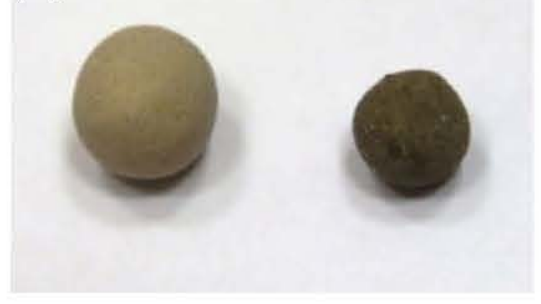

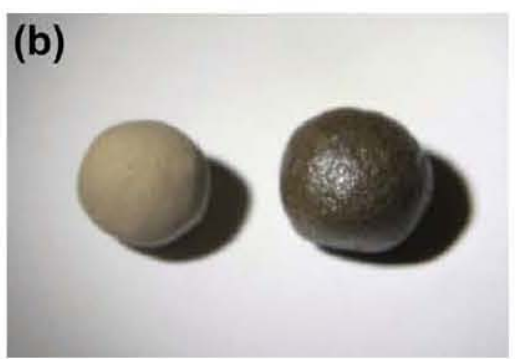

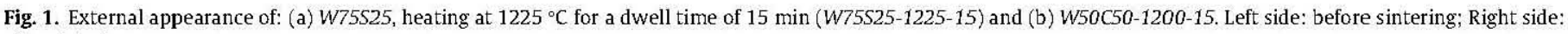
after sintering.

takes place only during the early stage because, at a later stage, when the chemical bond is stronger, this effect may not be so important [20].

The surfaces of LWAs manufactured with SS are not vitrified. Huang et al. [22] reported that a feed temperature of $850^{\circ} \mathrm{C}$ leads to green pellet surfaces being rapidly vitrified. W75S25-1150-10, W50S50-1150-10 and W25S75-1150-10 were pre-heated in the rotary kiln for $5 \mathrm{~min}$, but the temperature reached in this pre-heating area (approximately $600^{\circ} \mathrm{C}$ ) would not be high enough to produce vitrification of the surfaces. The aggregate surface of 
W50C50-1200-15 is the glossiest, which indicates that vitrification is more complete [22].

\subsubsection{Raw material composition relationship with microstructure}

To determine this relationship, special attention has been placed in the results of the microstructure of W75S25-1150-10, W50S50-1150-10 and W25S75-1150-10 since they have different compositions but they have been sintered with the same temperature and dwell time conditions.

None of the LWAs manufactured with $W$ and SS has a differentiated external layer (Fig. 2a-e). The particles are not vitrified and slight sintering is observed. There is no expansion. Despite of this, pores of variable size and shape are observed in the interior of the LWAs. The pore size is relatively small (Fig. 2b and d) and the shape is rather irregular. Most pores are elongated and interconnected, whereas only a few are discrete and spherical. They form during the heating process by gas release and/or sintering of the material. In the heating process of LWAs made up of $W$ and $S S$, gas release mainly occurs due to evaporation of the remaining moisture, high-temperature oxidation of organic matter and decarbonation of calcium carbonate, among other causes [14]. The emission and decomposition of the above-mentioned substances affects the macroscopic properties and the microstructure of the LWAs [23]. The gas released (i.e. loss on ignition, LOI) from the aggregates is directly related to the amount of $S S$ added [14]. Thus, the macroscopic properties and the microstructure of this type of LWAs are affected to a different extent, since they are manufactured with variable quantities of SS $(25 \%, 50 \%$ and $75 \%$ ).

EMPA analyses are in agreement with the SEM results: neither vitrification nor the development of bloating are observed (Fig. 3a-c). The original morphologies of the organic and inorganic fragments are recognized (chemical composition is shown in Table 3, point 1).
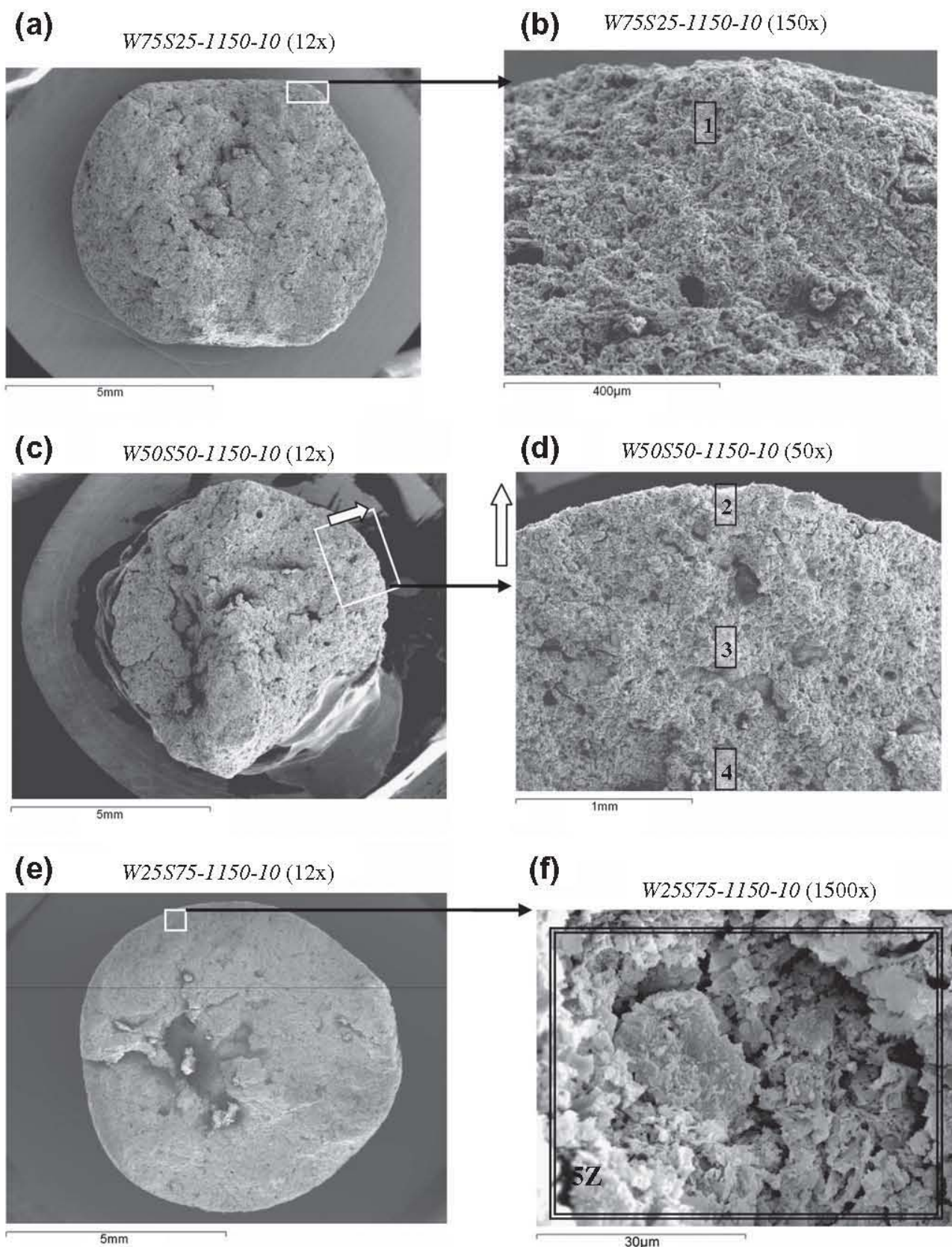

(f)

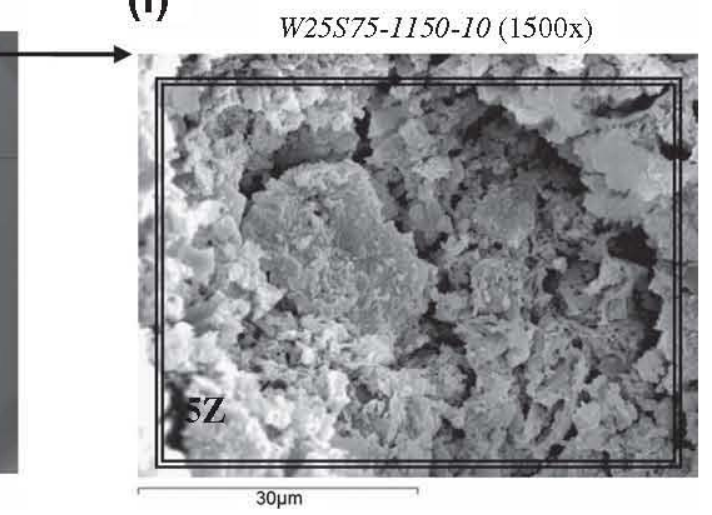

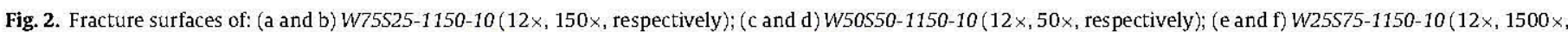
respectively). 1, 2, 3, 4: Chemical analysis points (Table 5). 5Z: Chemical analysis area (Table 5). 

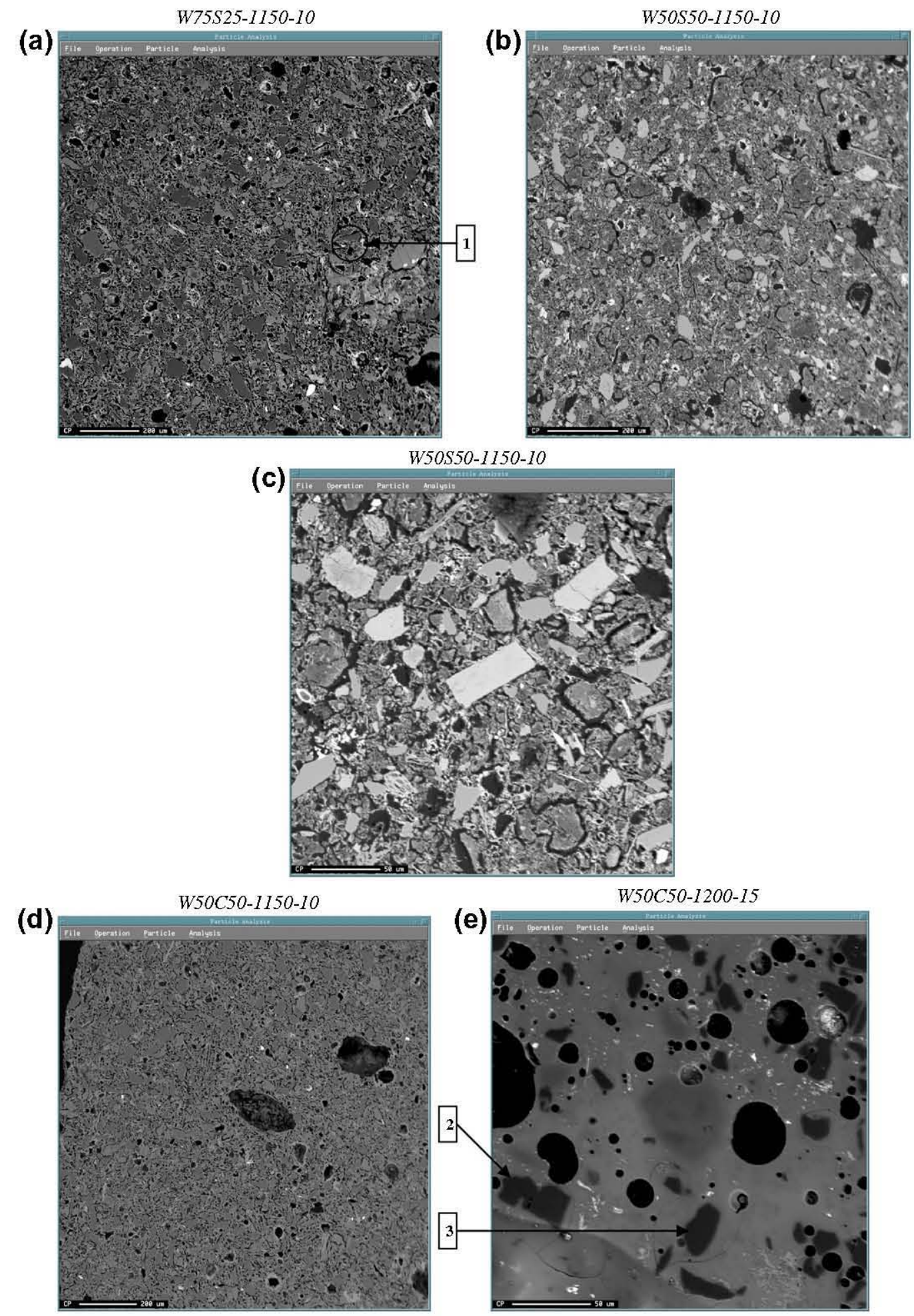

Fig. 3. EMPA images of: (a) W75525-1150-10; (b and c) W50550-1150-10; (d) W50C50-1150-10; (e) W50C50-1200-15. 1-3: Points analyzed by EMPA (Table 3). Black areas: pores.

As consequence of these observed results, it can be stated that the raw material composition affects the microstructure of the LWAs for two main reasons:

(i) depending on the initial composition, the proportion of gases released (LOI) will be variable; (ii) depending on the initial composition, the viscosity of the melted material will be appropriate to trap the released gases and expands.

In our case, the LWAs contain sufficient gas-producing components (LOI values between $24 \%$ and $48 \%$, Table 2 ) to achieve proper 
Table 3

Quantitative chemical composition of points analyzed by EMPA.

\begin{tabular}{|c|c|c|c|}
\hline $\begin{array}{l}\text { LWAs } \\
\text { Points (Fig. } 3 \text { ) } \\
\text { Element (\%wt) }\end{array}$ & $\begin{array}{l}\text { W75S25-1150-10 } \\
1\end{array}$ & $\begin{array}{l}\text { W50C50-1200-15 } \\
2\end{array}$ & 3 \\
\hline $\mathrm{SiO}_{2}$ & 99.44 & 100.13 & 100.55 \\
\hline $\mathrm{Al}_{2} \mathrm{O}_{3}$ & 0.02 & 0.01 & 0.01 \\
\hline $\mathrm{FeO}$ & 0.18 & 0.12 & 0.18 \\
\hline $\mathrm{MnO}$ & 0.03 & 0.00 & 0.00 \\
\hline $\mathrm{MgO}$ & 0.01 & 0.00 & 0.01 \\
\hline $\mathrm{CaO}$ & 0.04 & 0.04 & 0.03 \\
\hline $\mathrm{Na}_{2} \mathrm{O}$ & 0.01 & 0.01 & 0.00 \\
\hline $\mathrm{K}_{2} \mathrm{O}$ & 0.00 & 0.08 & 0.03 \\
\hline $\mathrm{TiO}_{2}$ & 0.18 & 0.01 & 0.04 \\
\hline $\mathrm{NiO}$ & 0.00 & 0.01 & 0.00 \\
\hline $\mathrm{Cr}_{2} \mathrm{O}_{3}$ & 0.01 & 0.00 & 0.00 \\
\hline $\mathrm{P}_{2} \mathrm{O}_{5}$ & 0.01 & 0.00 & 0.01 \\
\hline $\mathrm{SO}_{3}$ & 0.00 & 0.00 & 0.00 \\
\hline $\mathrm{F}$ & 0.00 & 0.02 & 0.02 \\
\hline $\mathrm{Cl}$ & 0.00 & 0.00 & 0.01 \\
\hline Total & 99.93 & 100.43 & 100.88 \\
\hline
\end{tabular}

bloating, but a pyroplastic state with the appropriate viscosity to trap gases is not achieved during the formation of these gases [24].

\subsubsection{Heating temperature and dwell time relationship with}

microstructure

The results of the microstructure of $W 50 C 50-1150-10$ and W50C50-1200-15 has been specially observed and compared since they have the same composition but they have been sintered with different conditions.

W50C50-1150-10 does not show a distinct external layer (Fig. 4a and b). In general, the material is highly sintered, with slight signs of expansion. Pores of variable diameter are observed. They are mostly regular in shape, spherical, discrete and closed.

Sample W50C50-1200-15 neither has the external layer, although it presents highly vitrified material with a thin external glassy film. As observed in Fig. $4 \mathrm{c}$ and d, there are clear signs of bloating, with abundant spherical pores within a wide size range, being generally small (the most abundant pores are approximately $100 \mu \mathrm{m}$ in size) and isolated. As has been described for some commercial aggregates (Lytag, [11]), the larger and smaller pores appear to be evenly mixed. The largest pores appear to be in the order of $500 \mu \mathrm{m}$. Their distribution throughout the cross-section is more uniform in this LWA type, treated at the highest temperature and dwell time, than in W50C50-1150-10 (Fig. 4a and b). The porous structure is due to the formation of gases in the molten material [11] with a pressure slightly higher than that required to resist the viscosity of the melted raw materials $[16,25]$. As reported by González-Corrochano et al. [14], gas release occurs due to the evaporation of the remaining moisture, dehydroxylation of clay minerals, such as kaolinite and illite, decarbonation of calcium carbonate and the gas evolution produced by the reaction of $\mathrm{Fe}_{2} \mathrm{O}_{3}$. The loss on ignition of the aggregates was not proportional to the temperature increase; therefore, if we only consider this factor, the macroscopic properties and the microstructure of W50C50 LWAs (Fig. 4) should not be affected to different extents, but they actually are. This means that the heating temperature and dwell time are important factors, since it affects the viscosity of the raw materials with which they must to trap the same amount of released gases.

As above, SEM results are in agreement with the EMPA analyses: at $1150^{\circ} \mathrm{C}$ and a dwell time of $10 \mathrm{~min}$, vitrification is not produced (Fig. 3d), whereas, at $1200^{\circ} \mathrm{C}$ and $15 \mathrm{~min}$, a glass structure with abundant pores and without an external shell is formed

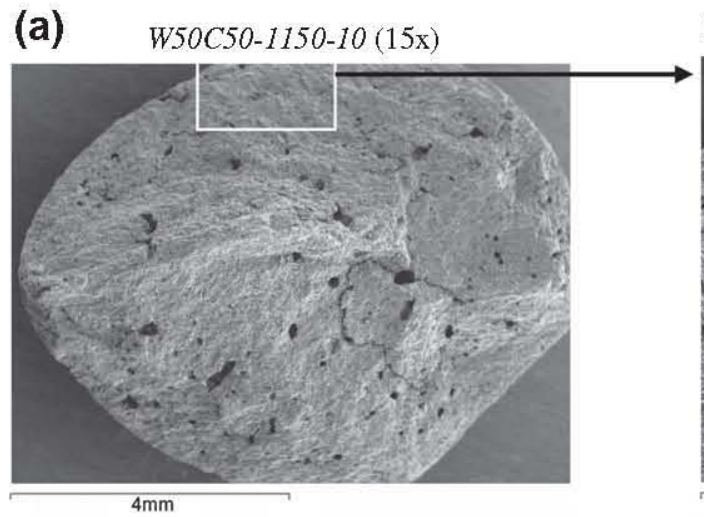

(b) W50C50-1150-10 (50x)
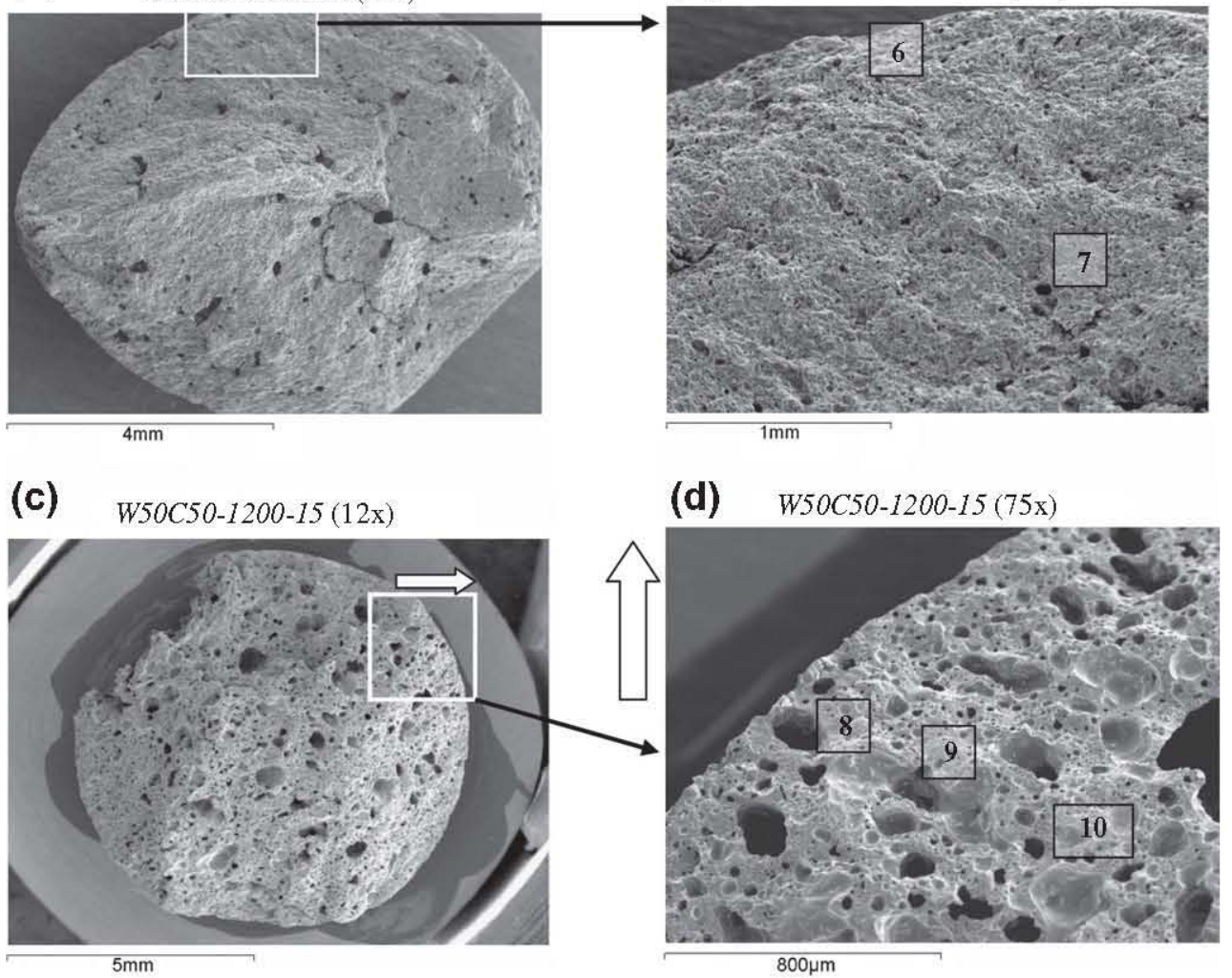

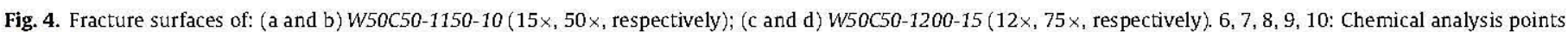
(Table 5). 
Table 4

Mineralogical composition of LWAs. Theating: Heating temperature; Qtz: Quartz; Plg: Plagioclases; Prx: Piroxenes; Geh: Gehlenite. +: 1-20\%; ++: 21-40\%; +++: 41-60\%; ++++: 61-80\%; +++++: $81-100 \%$.

\begin{tabular}{|c|c|c|c|c|}
\hline $\begin{array}{l}\text { Composition- } T_{\text {heating }} \text {-dwell } \\
\text { time (corresponding images) }\end{array}$ & Qtz & Plg & Prx & Geh \\
\hline W75S25-1150-10 (Figs. 2a, 2b, 3a, 5 and 7) & ++ & ++++ & & + \\
\hline W75S25-1150-15 & ++ & ++++ & + & \\
\hline$W 75525-1225-15$ & + & +++++ & & \\
\hline W50S50-1150-10 (Figs. 2c, 2d, 3b, 3c, 5 and 7 ) & ++ & ++++ & & + \\
\hline W25575-1150-10 (Figs. 2e, 2f and 7) & ++ & ++++ & & + \\
\hline W50C50-1150-10 (Figs. $3 \mathrm{~d}, 4 \mathrm{a}, 4 \mathrm{~b}$ and 7 ) & ++ & +++ & + & \\
\hline W50C50-1150-15 & ++ & +++ & + & \\
\hline W50C50-1200-15 (Figs. 3e, 4c, 4d and 7) & ++ & ++++ & & \\
\hline
\end{tabular}

(Fig. 3e). In W50C50-1200-15, some quartz grains (points 2 and 3, Table 3) can be observed in the vitrified matrix (Fig 3e).

\subsubsection{Raw material composition relationship with mineralogy}

The mineralogy of the raw materials was reported by GonzálezCorrochano et al. [14]: quartz, feldspars and phyllosilicates (illite, kaolinite and smectite) are present in different proportions in the $W$ and $C$ raw materials. $W$ also contains calcite and dolomite. SS does not contain any crystalline phases.

A comparison of the XRD data of W75S25-1150-10, W50S501150-10 and W25S75-1150-10 shows no differences between them (Table 4 and Fig. 5); therefore, in this case, the mineralogy of the LWAs is not influenced by the proportion of sewage sludge if $T_{\text {heating }}$ and the dwell time are the same. The most abundant crystalline phases are anorthite $\left(\mathrm{CaAl}_{2} \mathrm{Si}_{2} \mathrm{O}_{8}\right)$ and quartz $\left(\mathrm{SiO}_{2}\right)$; the latter probably reflects mineralogical relics of $W$. The presence of gehlenite $\left(\mathrm{Ca}_{2} \mathrm{Al}_{2} \mathrm{SiO}_{7}\right)$ is also detected. Since, in the raw materials, anorthite is a minor trace component and there is no gehlenite, these may be considered to be neo-formed minerals. These minerals are Ca-bearing minerals and this element only appears in the raw materials as calcite $\left(\mathrm{CaCO}_{3}\right)$ and dolomite $\left(\mathrm{CaMg}\left(\mathrm{CO}_{3}\right)_{2}\right)$. The neo-formation of anorthite and gehlenite could be promoted by the availability of $\mathrm{CaO}$, caused by the decarbonation of calcite at $750^{\circ} \mathrm{C}$, as revealed by the thermogravimetry-differential thermal analysis (TG-DTA) performed in the previous study [14]. CaO is very reactive and highly sinterable [26,27], and it may react with the products from the dehydroxylation of the clay minerals, such as kaolinite and illite, also observed by TG-DTA in the raw materials at about $520^{\circ} \mathrm{C}$. This hypothesis is supported by the absence of phyllosilicates, calcite and dolomite in the sintered samples. In fact, the neo-formation of gehlenite by the reaction of $\mathrm{CaO}$ with meta-kaolin and/or kaolinite has been reported [28-30].

\subsubsection{Heating temperature and dwell time relationship with mineralogy}

In the case of LWAs with $25 \%$ of SS, increasing the dwell time at $1150^{\circ} \mathrm{C}$ does not cause significant mineralogical changes, since $W 75 S 25-1150-10$ and $W 75 S 25-1150-15$ show the same proportion of anorthite and quartz ( $61-80 \%$ and $21-40 \%$, respectively). Instead of gehlenite, pyroxene group minerals are detected (such as ferroan diopside ( $\mathrm{Ca}(\mathrm{Mg}, \mathrm{Fe}) \mathrm{Si}_{2} \mathrm{O}_{6}$ ), Table 4) in W75S25-1150-15. Pyroxenes have also been identified in LWAs and glass-ceramics prepared from different types of wastes $[4,31,32]$. They can be regarded as neo-formed minerals, since the raw materials ( $W$ and $S S$ ) do not contain pyroxenes. A possible neo-formation mechanism would be substitutions of the $\mathrm{Ca}$ in the original structure of wollastonite $\left(\mathrm{CaSiO}_{3}\right)$ for $\mathrm{Mg}$ and $\mathrm{Fe}$. Wollastonite was formed by the reaction of calcite and quartz, accompanied by $\mathrm{CO}_{2}$ release, at temperatures higher than $600-700^{\circ} \mathrm{C}$ [31]. This neo-formation

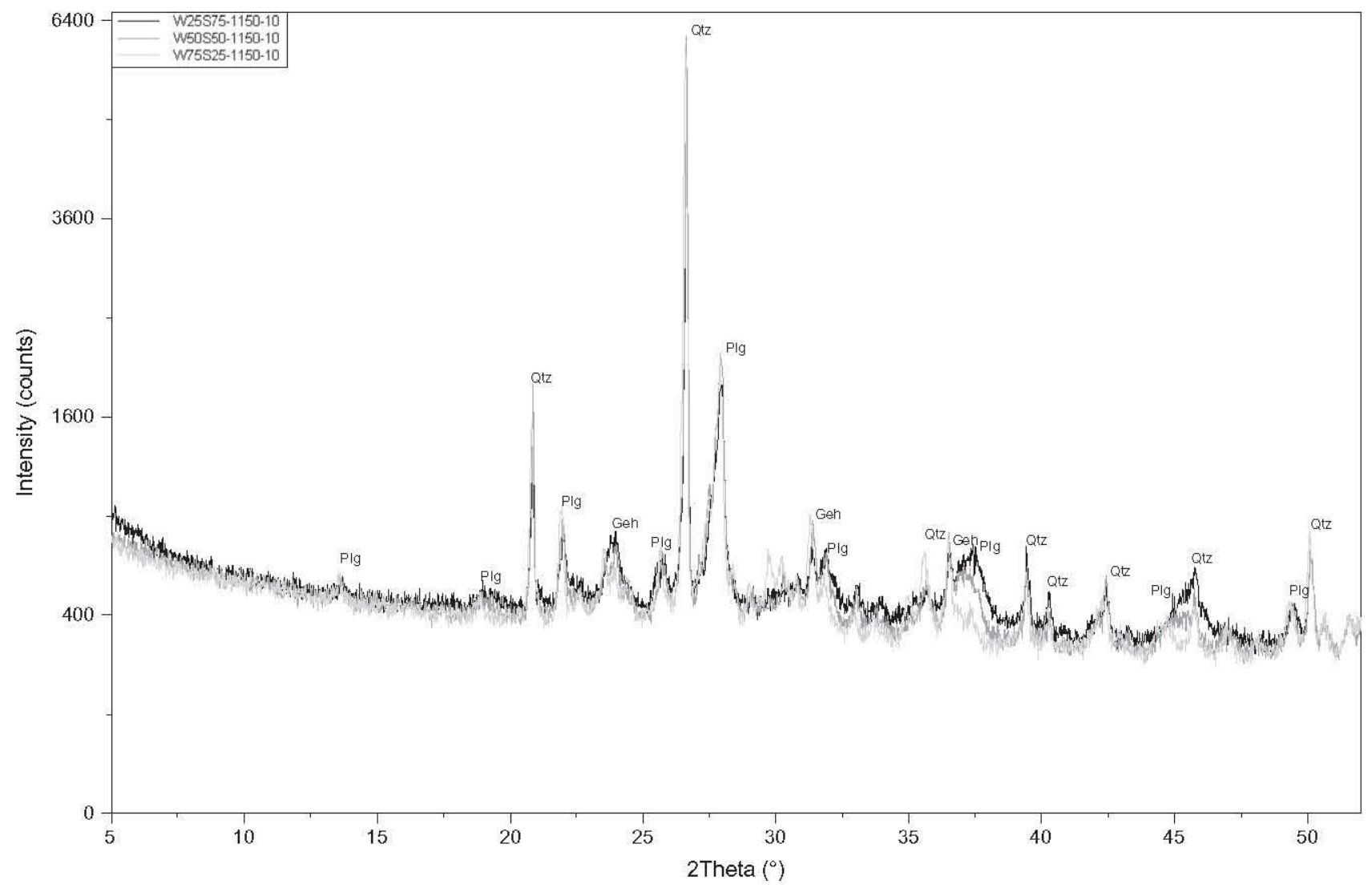

Fig. 5. XRD patterns of W75525-1150-10, W50550-1150-10 and W25575-1150-10 samples. Qtz: Quartz; Plg: Plagioclases; Geh: Gehlenite. 
mechanism has been reported for raw materials containing quartz and calcite and lacking clay minerals, such as illite. In this study, the washing aggregate sludge is also composed of clay minerals; therefore, an alternative neo-formation mechanism must exist, such as reaction of the clay minerals with the calcium resulting from the decarbonation of calcite. The proportion of pyroxenes increases with time at $1150^{\circ} \mathrm{C}$, but does not change with temperature. This is in agreement with previous studies [33], where the relative amount of diopside and wollastonite increases with temperatures up to $900^{\circ} \mathrm{C}$ (maximum crystallinity) and decreases above this temperature. The same occurs when the dwell time is longer than $20 \mathrm{~min}$.

Increasing temperatures produce qualitative mineralogical changes, such as the disappearance of pyroxenes, in LWAs with the same composition (W75S25-1150-15 and W75S25-1225-15), and also cause quantitative changes: the amount of quartz decreases and that of anorthite increases (Table 4). The observed decrease in the amount of quartz could be related to the consumption of this mineral during the formation of the glassy phase [30] or other crystalline phases. The phyllosilicates, calcite and dolomite originally in the $W$ raw material are not detected in the sintered samples, which supports the hypothesis that these minerals have been consumed during the production of the neo-formed phases (anorthite, gehlenite and pyroxenes).

The mineralogy of LWAs with $W$ and $C$ undergoes significant qualitative and quantitative changes when the temperature and the dwell time increase. Quartz, plagioclase and pyroxenes are present in W50C50-1150-10 and W50C50-1150-15 (Table 4), and their origin could be the same as that described above for LWAs with SS. Augite ([Ca,Mg,Fe,Ti, $\left.\mathrm{Al}]_{2}(\mathrm{Si}, \mathrm{Al})_{2} \mathrm{O}_{6}\right)$ is more abundant in samples heated for a dwell time of $10 \mathrm{~min}$, whereas, in those heated for $15 \mathrm{~min}$, diopside $\left(\mathrm{CaMgSi}_{2} \mathrm{O}_{6}\right)$ is present in a greater proportion. This means that a 5-min increase in the dwell time causes changes among members of the same solid solution. As in the case of LWAs with SS, the proportion of pyroxene group minerals decreases with increasing $T_{\text {heating, }}$ until they disappear, as reported by Romero et al. [33].

These mineralogical data can be helpful to determine the nature of some of the structures observed in Fig. 6. The lamellar crystals shown in Fig. 6a (corresponding to W75S25-1150-10) could be relics of phyllosilicates, since the amounts of calcium $(\mathrm{Ca}=0.68 \%$, semi-quantitative analysis: Table 5 , point 11) are too low for them to be anorthite $(\mathrm{Ca}=13.72 \%)$ or gehlenite $(\mathrm{Ca}=29.23 \%)$, the neoformed minerals in this type of LWA. The structures shown in Fig. $6 \mathrm{~b}$ and $\mathrm{c}$ (corresponding to W50C50-1200-15) could also be relics of dehydroxylated illite; they are not anorthite crystals because their iron content (Table 5 , zone $12 \mathrm{Z}$ and point 13 ) is relatively high.

As seen above, there are relationships between raw material composition/heating temperature/dwell time - microstructure/mineralogy of LWAs. The main observed relationships of this type are summarized in Table 6.

\subsection{Relationship between microstructure/mineralogy - physical properties}

The results for the BI, $\rho_{d}, W_{24 h}$ and $S$ tests of the LWAs studied by SEM are shown in Table 1 and Fig. 7 . Table 7 presents a summary of the main relationships between microstructure and/or mineralogy of the studied LWAs and their physical properties.

\subsubsection{Microstructure relationship with bloating index}

Instead of expanding, as it is expected since it is located inside of the bloating area of the Riley ternary diagram, BI of mixture W75S25 undergoes a progressive decrease as the heating temperature increase (Table 1). This could be due to the absence of the

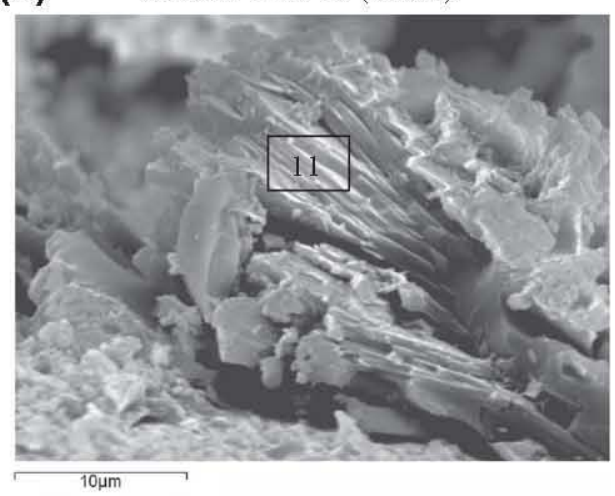

(b)

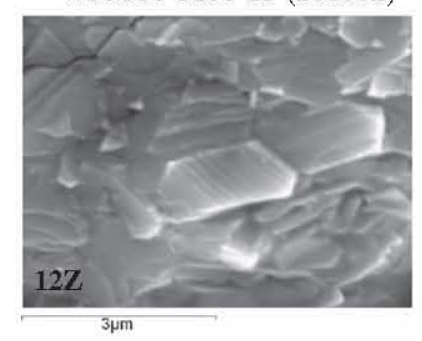

(c) $650 C 50-1200-15(15000 \mathrm{x})$

Fig. 6. Crystalline structures observed in: (a) W75525-1150-10 (3500x); (b) and (c) W50C50-1200-15 $(20,000 \times, 15,000 \times$, respectively). 11, 13: Chemical analysis points (Table 5). 12Z: Chemical analysis area (Table 5).

formation of a vitrified layer (Fig. $2 a$ and b) that could have enveloped the gas produced in the process [22].

BI is influenced by the microstructure of the LWAs. This fact can be clearly detected comparing Fig. 4 and Fig. 7: BI of W50C50-120015 is higher of BI of W50C50-1150-10 (Fig. 7a), being the microstructure of this LWA (Fig. $4 \mathrm{a}$ and b) less porous than the microstructure of W50C50-1200-15 (Fig. 4c and d).

\subsubsection{Microstructure/mineralogy relationship with dry particle density}

Two factors should be taken into account when changes in density are considered: the changes in porosity and the changes in the solid density of the aggregate [13]. As mentioned above, no qualitative mineralogical differences exist between W75S25-1150-10, W50S50-1150-10 and W25S75-1150-10 (Table 4 and Fig. 5); therefore, the differences in density (Fig. 7b) could be more related to the microstructure than to the crystalline phases. BSE images reveal larger, more abundant pores (black areas) in W50S501150-10 (Fig. 3b) than in W75S25-1150-10 (Fig. 3a). This means a lower mass for the same volume of LWAs or, in other words, a lower particle density value.

The sintering of $W 50 C 50$ samples at $1200^{\circ} \mathrm{C}$ produces LWAs with densities that are lower than those sintered at $1150^{\circ} \mathrm{C}$ (Fig. 7b), although they are higher than those obtained for LWAs with SS. The decrease in density in sample W50C50-1200-15 is attributed to bloating (Table 1 and Fig. 7a); this hypothesis is supported by the presence of a large number of pores, as shown in Figs. $3 e, 4 c$ and $d$. Another factor that could contribute to this decrease is the mineralogical change that takes place with an increase in temperature (Table 4), namely, the disappearance of pyroxenes, mainly augite (density of $3.19-3.56 \mathrm{~g} / \mathrm{cm}^{3},[34]$ ), and the neo-formation of a greater proportion of plagioclase, such as anorthite (average density of $2.76 \mathrm{~g} / \mathrm{cm}^{3}$, [34]), which entails a change in the density of the solid material in the LWAs. 
Semi-quantitative chemical composition of points and areas $(-Z)$ of LWAs. n.d: not determined.

\begin{tabular}{|c|c|c|c|c|c|c|c|c|c|c|c|c|}
\hline $\begin{array}{l}\text { Element (\% wt) } \\
\text {-Point or zone }(-Z) \\
\text {-LWA } \\
\text {-Figure where it is marked }\end{array}$ & C & $\mathrm{Na}$ & $\mathrm{Mg}$ & $\mathrm{Al}$ & $\mathrm{Si}$ & $\mathrm{K}$ & $\mathrm{Ca}$ & $\mathrm{Ti}$ & $\mathrm{Mn}$ & $\mathrm{Fe}$ & 0 & Total \\
\hline $\begin{array}{l}-1 \\
-W 75525-1150-10 \\
\text {-Fig. 2b }\end{array}$ & 0.00 & 0.00 & 0.81 & 7.12 & 10.90 & 0.00 & 33.45 & 0.00 & 0.00 & 11.02 & 35.85 & 100.00 \\
\hline $\begin{array}{l}-2 \\
-W 50550-1150-10 \\
\text {-Fig. 2d }\end{array}$ & 8.67 & n.d. & 0.66 & 12.26 & 11.30 & n.d. & 10.36 & 0.36 & n.d. & 3.64 & 52.74 & 100.00 \\
\hline $\begin{array}{l}-3 \\
-W 50550-1150-10 \\
-F i g .2 d\end{array}$ & 2.54 & n.d. & 6.48 & 8.29 & 10.72 & n.d. & 15.71 & 0.68 & n.d. & 14.17 & 41.40 & 100.00 \\
\hline $\begin{array}{l}-4 \\
-W 50550-1150-10 \\
- \text { Fig. } 2 d\end{array}$ & n.d. & n.d. & 1.06 & 18.81 & 13.44 & 0.91 & 16.44 & n.d. & n.d. & 7.65 & 41.68 & 100.00 \\
\hline $\begin{array}{l}-5 Z \\
-W 25575-1150-10 \\
- \text { Fig. 2f }\end{array}$ & 0.00 & 0.45 & 0.99 & 24.89 & 14.93 & 1.45 & 7.10 & 0.29 & 0.00 & 3.85 & 45.06 & 100.00 \\
\hline $\begin{array}{l}-6 \\
-W 50 C 50-1150-10 \\
- \text { Fig. } 4 b\end{array}$ & 10.47 & 0.00 & 1.66 & 5.74 & 14.59 & 0.64 & 7.36 & 0.00 & 0.00 & 4.45 & 55.07 & 100.00 \\
\hline $\begin{array}{l}-7 \\
-W 50 C 50-1150-10 \\
\text {-Fig. } 4 b\end{array}$ & 8.76 & 0.00 & 1.08 & 3.73 & 22.72 & 1.33 & 3.29 & 0.20 & 0.00 & 3.07 & 55.83 & 100.00 \\
\hline $\begin{array}{l}-8 \\
-W 50 C 50-1200-15 \\
-F i g .4 d\end{array}$ & n.d. & n.d. & 2.41 & 7.34 & 28.58 & 2.74 & 4.96 & n.d. & n.d. & 8.35 & 45.61 & 100.00 \\
\hline $\begin{array}{l}-9 \\
-W 50 C 50-1200-15 \\
- \text { Fig. } 4 d\end{array}$ & n.d. & n.d. & 2.15 & 7.49 & 28.31 & 2.86 & 5.02 & 0.64 & n.d. & 7.91 & 45.61 & 100.00 \\
\hline $\begin{array}{l}-10 \\
-W 50 C 50-1200-15 \\
\text {-Fig. 4d }\end{array}$ & n.d. & n.d. & 2.26 & 7.52 & 28.74 & 2.62 & 5.16 & n.d. & n.d. & 7.92 & 45.78 & 100.00 \\
\hline $\begin{array}{l}-11 \\
\text {-Crystalline structure of W75525-1150-10 } \\
\text {-Fig. 6a }\end{array}$ & 0.00 & 0.71 & 0.00 & 17.53 & 24.56 & 7.43 & 0.68 & 0.36 & 0.00 & 1.19 & 46.29 & 100.00 \\
\hline $\begin{array}{l}-12 Z \\
\text {-Crystalline structure of W50C50-1200-15 } \\
\text {-Fig. 6b }\end{array}$ & n.d. & n.d. & 3.65 & 6.73 & 14.79 & 1.37 & 7.18 & 0.60 & n.d. & 28.09 & 37.58 & 100.00 \\
\hline $\begin{array}{l}-13 \\
\text {-Crystalline structure of W50C50-1200-15 } \\
\text {-Fig. 6c }\end{array}$ & n.d. & n.d. & 4.56 & 7.94 & 19.38 & 2.74 & 3.72 & 0.55 & n.d. & 20.58 & 40.52 & 100.00 \\
\hline
\end{tabular}

\subsubsection{Microstructure/mineralogy relationship with water absorption}

Water absorption values for sintered LWAs decrease as the proportion of SS raw material decreases (types W25S75, W50S50 and W75S25) and the firing temperature increases (type W50C50) (Fig. 7c), which indicates a reduction in the volume of water accessible surface-connected porosity [5]. Regardless of the heating temperature and/or time, W50C50 produces pellets with very low water absorption.

The water absorption of sample W25S75-1150-10 is higher than that of W50S50-1150-10 and W75S25-1150-10 (Fig. 7c), because there are more released gases in the former ( $\mathrm{LOI}=40 \%,[14])$ and they have generated a high open porosity between the particles (Figs. 2, 3a and b).

Zhang and Gjørv [21] have demonstrated the effect of a dense external shell on the reduction in water absorption for whole and cut particles. Even though W50C50-1150-10 (Figs. 3d, 4a and b) and $W 50 C 50-1200-15$ (Figs. $3 e, 4 c$ and d) do not show an external shell, they have the lowest water absorption values (Fig. 7c) because they present closed porosity [5]. In addition, sample W50C50-1200-15 (Figs. 3e, 4c and d) has vitrified material with an external glassy film, which makes the outer surface impervious to water [35], although new porosity has formed due to bloating.
Huang et al. [22] have reported the formation of a well-vitrified surface in LWAs when the water absorption rate is less than $10 \%$; this is in agreement with the results obtained for sample W50C50-1200-15 (Fig. 7c). This means that the presence of isolated pores is as important as the presence of an external shell.

\subsubsection{Microstructure/mineralogy relationship with compressive strength}

Some properties of structural lightweight concrete, such as strength and dimensional stability, depend to a large extent on the strength of the LWAs, since, unlike in normal-weight concrete, the aggregate is the weakest component of the system, and not the interfacial transition zone, where, due to the pozzolanic reaction, the bond strength between aggregate/cement is stronger than the individual LWA particles [20]. The compressive strength values of the LWAs studied are shown in Fig. $7 \mathrm{~d}$. The value for sample W25S75-1150-10 is the lowest. Elongated, interconnected pores (Fig. $2 \mathrm{e}$ and $\mathbf{f}$ ) are one of the causes of the low $S$ value [21]. Sintering at $1150^{\circ} \mathrm{C}$ for $10 \mathrm{~min}$ of the LWAs manufactured with SS, regardless of the proportion of sludge, produces a granular material that is relatively poorly sintered (Fig. 2). The low compressive strength data obtained for this type of samples are in agreement 
Observed relationships between the composition/heating temperature/dwell time in the microstructure/mineralogy of the studied LWAs.

\begin{tabular}{|c|c|c|c|}
\hline & Raw material composition & Temperature & Dwell time \\
\hline \multirow[t]{6}{*}{$\begin{array}{l}\text { Surface and } \\
\text { microstructure }\end{array}$} & $\begin{array}{l}\text { - No relationship between raw material } \\
\text { composition and particle shape }\end{array}$ & $\begin{array}{l}\text { - No relationship between } T_{\text {heating }} \text { and particle } \\
\text { shape }\end{array}$ & $\begin{array}{l}\text { - No relationship between dwell time } \\
\text { and particle shape }\end{array}$ \\
\hline & $\begin{array}{l}\text { - Increased proportion of SS results in LWAS with } \\
\text { rougher surface texture }\end{array}$ & $\begin{array}{l}\text { - Increased } T_{\text {heating }} \text { results in increased } T^{\mathrm{T}} \text { in the } \\
\text { pre-heating area producing vitrification of the }\end{array}$ & $\begin{array}{l}\text { e.g. } W 75525-1150-10 \text { and } W 75525- \\
1150-15 \text { present the same particle }\end{array}$ \\
\hline & $\begin{array}{l}\text { - LWAs with C present vitrified surface vs LWAs } \\
\text { with SS that do not present vitrified surface }\end{array}$ & surface & shape (rounded and sub-spherical) \\
\hline & $\begin{array}{l}\text { - Different raw material composition results in } \\
\text { different loss on ignition values (gas release) } \\
\text { producing different porosity grade }\end{array}$ & \multicolumn{2}{|c|}{$\begin{array}{l}\text { - Increased } T_{\text {heating }} \text { and dwell time promote the production of highly internal vitrified } \\
\text { material }\end{array}$} \\
\hline & $\begin{array}{l}\text { - Different raw material composition results in } \\
\text { different BI values (gas release and viscosity of the }\end{array}$ & \multicolumn{2}{|c|}{$\begin{array}{l}\text { - Different } T_{\text {heating }} \text { and dwell time result in different viscosity of the melted raw materials to } \\
\text { trap the same proportion of gases producing different type and porosity grade }\end{array}$} \\
\hline & & \multicolumn{2}{|c|}{$\begin{array}{l}\text { e.g. W50C50-1150-10 has different microstructure than } W 50 C 50-1200-15 \text { although their loss } \\
\text { on ignition (gas release) is similar [14] }\end{array}$} \\
\hline \multirow[t]{4}{*}{ Mineralogy } & $\begin{array}{l}\text { - No relationship between proportion of } S S \text { in the } \\
\text { LWAs and mineralogy (if } T_{\text {heating }} \text { and dwell time } \\
\text { are the same) }\end{array}$ & $\begin{array}{l}\text { - Increased } T_{\text {heating }} \text { promotes qualitative and } \\
\text { quantitative mineralogical changes } \\
\text { (disappearance of pyroxenes and neo-formation } \\
\text { of a greater proportion of plagioclase) }\end{array}$ & $\begin{array}{l}\text { - Dwell time effect on mineralogy } \\
\text { depends on the raw material }\end{array}$ \\
\hline & $\begin{array}{l}\text { e.g. W75525-1150-10, W50550-1150-10 and } \\
\text { W25575-1150-10 present the same mineralogical } \\
\text { phases (quartz, anorthite and gehlenite, Table 4) }\end{array}$ & $\begin{array}{l}\text { - Increased } T_{\text {heating }} \text { results in glassy material neo- } \\
\text { formation }\end{array}$ & $\begin{array}{l}\text { e.g. LWAs with SS: increased dwell time } \\
\text { produces disappearance of gehlenite } \\
\text { and neo-formation of pyroxenes }\end{array}$ \\
\hline & & & $\begin{array}{l}\text { LWAs with } C \text { : increased dwell time } \\
\text { promotes changes of among of } \\
\text { members of the same solid solution } \\
\text { (augite changes to diopside) }\end{array}$ \\
\hline & & \multicolumn{2}{|c|}{$\begin{array}{l}\text { - Thermal treatment promotes mineralogical neo-formation (anorthite, gehlenite, piroxenes) } \\
\text { - Increased } T_{\text {heating and dwell time result in qualitative and quantitative mineralogical }} \\
\text { changes (disappearance of pyroxenes and neo-formation of a greater proportion of } \\
\text { plagioclase) }\end{array}$} \\
\hline
\end{tabular}

(a)

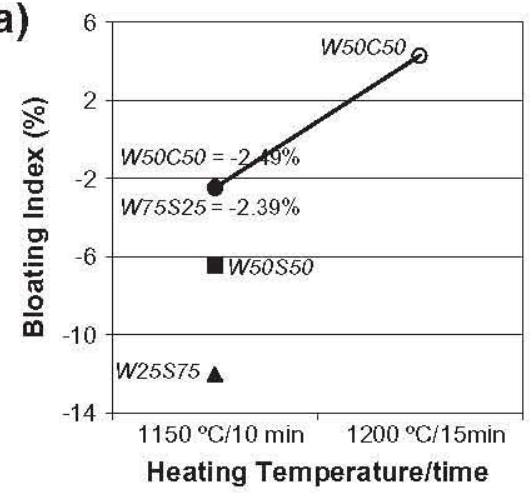

(c)

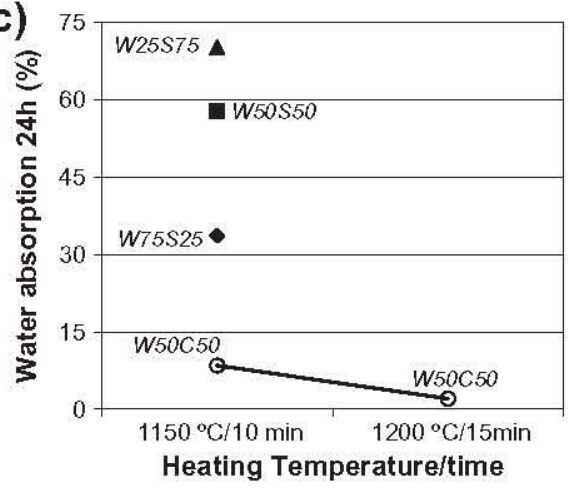

(b)

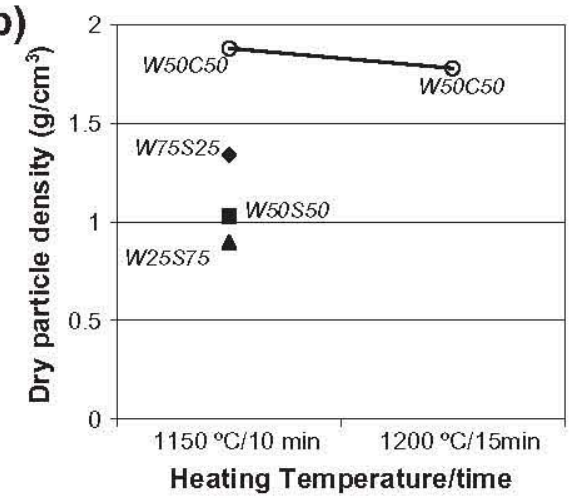

(d)

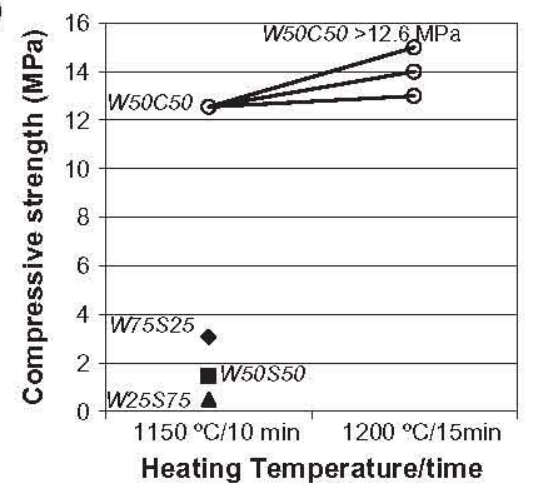

Fig. 7. According to [14], main properties of LWAs studied by SEM. (a) Bloating index; (b) dry particle density; (c) water absorption; (d) compressive strength.

with the images observed, because breakage occurs primarily between particles [5]. The mineral species in the LWAs and the nature of the newly formed phases could be another factor affecting compressive strength values $[36,37]$. Since the mineralogical phases in W75S25-1150-10, W50S50-1150-10 and W25S75-115010 are the same (Table 4 ), it can be concluded that microstructural 


\begin{tabular}{|c|c|c|}
\hline & Microstructure & Mineralogy \\
\hline Bloating index & $\begin{array}{l}\text { - Absence of formation of a vitrified layer with an increased } \\
\text { temperature results in a progressive decrease in the BI } \\
\text { - Greater proportion and larger size of closed inner pores produce } \\
\text { increased BI }\end{array}$ & \\
\hline \multirow[t]{2}{*}{ Dry particle density } & - Larger and more abundant pores result in lower $\rho_{d}$ values & $\begin{array}{l}\text { - Mineralogical changes with increased temperature } \\
\text { (disappearance of pyroxenes and neo-formation of plagioclase) } \\
\text { produce lower } \rho_{d} \text { values }\end{array}$ \\
\hline & $\begin{array}{l}\text { e.g. } \rho_{d} \text { of } W 50 C 50-1200-15 \text { (see Table } 1 \text { and Fig. } 4 \mathrm{c}-\mathrm{d} \text { : large and } \\
\text { abundant pores) is lower than } \rho_{d} \text { of } W 50 C 50-1150-10 \text { (see Table } 1 \\
\text { and Fig. } 4 \mathrm{a} \text { and b: small and few pores) }\end{array}$ & $\begin{array}{l}\text { e.g. } \rho_{d} \text { of } W 50 C 50-1200-15 \text { (see Table } 1 \text { ) is lower than } \rho_{d} \text { of } \\
W 50 C 50-1150-10 \text { (see Tables } 1 \text { and } 4 \text { ) }\end{array}$ \\
\hline Water absorption & $\begin{array}{l}\text { - High open porosity between particles results in higher } W A_{24 h} \\
\text { values } \\
\text { - Presence of a external glassy film (although with neo-formed } \\
\text { porosity) results in lowest } W A_{24 h} \text { values } \\
\text { - Closed porosity (although without a dense external shell) results } \\
\text { in lowest WA } A_{24 h} \text { values } \\
\text { - In the permeability of the LWAs, the presence of isolated pores is } \\
\text { a factor as important as the presence of an external shell }\end{array}$ & - Vitrified material results in lowest $W_{A_{24} \mathrm{~h}}$ values \\
\hline Compressive strength & $\begin{array}{l}\text { - Presence of a external glassy film promotes higher } S \text { values } \\
\text { - Granular and relatively poorly sintered material results in lower } \\
S \text { values } \\
\text { - Elongated and interconnected pores produce the lowest } S \text { value } \\
\text { - Closed, not fused, regular in shape and size, relatively small and } \\
\text { uniformly distributed pores results in higher } S \text { values } \\
\text { - Relationship between porosity grade (number of pores) and } S \\
\text { values is lower than relationship between type of porosity and } S \\
\text { values }\end{array}$ & $\begin{array}{l}\text { - Greater proportion of silicate glass and calcium silicates, } \\
\text { especially anorthite, results in an improvement of the } S \text { values } \\
\text { e.g. } 5 \text { of } W 50 C 50-1200-15 \text { (see Table } 1 \text { ) is higher than } S \text { of W50C50 } \\
1150 \text { - } 10 \text { (see Tables } 1 \text { and } 4 \text { ) }\end{array}$ \\
\hline
\end{tabular}

differences are the most important factor to explain the different compressive strength values in LWAs with SS, sintered at $1150^{\circ} \mathrm{C}$ for a dwell time of $10 \mathrm{~min}$.

Lightweight aggregates with less pores have a higher compressive strength than LWAs with the lowest density (more pores) $[22,37]$. This is not in accordance with our results, because, although W50C50-1200-15 (Fig. 4c and d) presents more and larger pores than W50C50-1150-10 (Fig. 4a and b), the former has a higher compressive strength, primarily due to the fact that the new pores are closed, not fused, regular in shape and size, relatively small [5] and uniformly distributed, and also to the presence of an external glassy film [35]. Moreover, the presence of a greater proportion of glassy phase could be another reason for the higher compressive strength of W50C50-1200-15 as compared to W50C50-1150-10, since larger amounts of silicate glass and calcium silicate, especially anorthite, improve the strength of clay-based ceramics [30]. Accordingly, the aggregate particles are strong, and unlike LWAs with SS, they are capable of producing structural concrete [20].

\section{Conclusions}

The microstructural and mineralogical results obtained for the LWAs in this study, along with previous complementary data [14], allow us to establish the following conclusions:

(i) The initial raw materials, the heating temperature and the dwell time affect the degree of vitrification of the lightweight aggregate material and the formation of pores inside it.

(ii) The mineralogical analysis reveals that the main crystalline phases identified in LWAs manufactured with sewage sludge are quartz $\left(\mathrm{SiO}_{2}\right)$ and neo-formed anorthite $\left(\mathrm{CaAl}_{2} \mathrm{Si}_{2} \mathrm{O}_{8}\right)$. Neo-formed ferroan diopside $\left(\mathrm{Ca}[\mathrm{Mg}, \mathrm{Fe}] \mathrm{Si}_{2} \mathrm{O}_{6}\right)$ and gehlenite $\left(\mathrm{Ca}_{2} \mathrm{Al}_{2} \mathrm{SiO}_{7}\right)$ are also recorded in the XRD patterns. In LWAs with washing aggregate sludge and clay-rich sediment, the main phases are quartz and neo-formed anorthite $\left(\mathrm{CaAl}_{2-}\right.$ $\left.\mathrm{Si}_{2} \mathrm{O}_{8}\right)$, augite $\left([\mathrm{Ca}, \mathrm{Mg}, \mathrm{Fe}, \mathrm{Ti}, \mathrm{Al}]_{2}(\mathrm{Si}, \mathrm{Al})_{2} \mathrm{O}_{6}\right)$ and diopside $\left(\mathrm{CaMgSi}_{2} \mathrm{O}_{6}\right)$. With increasing heating temperatures, the proportion of quartz decreases, whereas that of plagioclase increases.

(iii) The more important and specific relationships between microstructure/mineralogy and the properties of the LWAs have been:

- Microstructure - bloating index: the absence of formation of a vitrified layer with an increased temperature could influence a progressive decrease of the BI. Higher BI values can be correlated with a greater proportion and larger size of closed inner pores.

- Microstructure - dry particle density: larger, more abundant pores can be observed when the $\rho_{d}$ of the LWAs decreases.

- Mineralogy - dry particle density: the disappearance of pyroxene and the neo-formation of a greater proportion of plagioclase could produce a decrease in the density of the solid material in the LWAs.

- Microstructure - water absorption: when an external glassy film is formed in the LWAs, $W_{24 h}$ is not related to the size, number and/or type of pores in the interior. In the permeability of the LWAs, the presence of isolated pores is a factor as important as the presence of an external shell.

- Mineralogy - water absorption: the formation of a glassyvitrified phase reduces water absorption.

- Microstructure - crushing strength: granular material, which is poorly sintered, and elongated, interconnected pores cause a worsening of $S$ values. However, the presence of an external glassy film and of closed, not fused, small, uniformly distributed pores, with a regular shape and size, increases the $S$ values. Type and distribution of pores in the LWAs is more determinant in the $S$ values of them than the number of pores. 
- Mineralogy - crushing strength: the presence of calcium silicates, especially anorthite, and the consumption of quartz during the formation of the glassy phase improve the $S$ values.

It must be highlighted that, at the microscopic level, concrete can be considered to be a three-phase material: (i) aggregate phase, (ii) hydrated cement paste, and (iii) interfacial transition zone. Each of these phases is itself multiphase in character. Although a detailed microstructural and mineralogical study of LWAs has been carried out in this work, studies of each of the two other phases and the interrelationships between them are essential to control the properties of concrete [20]. This work is, therefore, a preliminary approach to the possible characteristics of concretes manufactured with the LWAs studied. Further laboratory studies, such as concrete manufacturing and testing, will be carried out in order to determine the actual applications of the LWAs obtained.

\section{Acknowledgment}

The financial support from the Junta de Comunidades de CastillaLa Mancha (Project PBI-05-044 and Project PCI08-0027) and the Obra Social Caja Madrid of Spain is gratefully acknowledged.

\section{References}

[1] Bodycomb FM, Stokowski S]. Construction uses-insulation. Industrial minerals and rocks. London: SME; 2000.

[2] Mason BH. Construction uses-lightweight aggregates. Industrial minerals and rocks. London: SME; 2000.

[3] Weinecke MH, Faulkner BP. Production of lightweight aggregates from waste materials. Miner Eng 2002:54:1-5.

[4] Cheeseman CR, Makinde A, Bethanis S. Properties of lightweight aggregate produced by rapid sintering of incinerator bottom ash. Resour Conserv Recycl 2005;43:147-62.

[5] Cheeseman CR, Virdi GS. Properties and microstructure of lightweight aggregate produced from sintered sewage sludge ash. Resour Conserv Recycl 2005;45:18-30.

[6] Aitcin PC, Mehta PK. Effect of coarse-aggregate characteristics on mechanical properties of high-strength concrete. ACI Mater J 1990;87:103-7.

[7] Lo Y, Gao XF, Jeary AP. Microstructure of pre-wetted aggregate on lightweight concrete. Build Environ 1999;34:759-64.

[8] Rice RW, Dekker M. Porosity of ceramics. New York: Elsevier; 1998.

[9] Bijen J. Fly ash aggregates. In: Proceeding international conference: use of fly ash, silica fume, slag and other mineral by products in concrete. Montebelo conference, USA; 1983

[10] Hwang C, Lin R, Hsu K, Chan J. Granulation of fly ash lightweight aggregate and accelerated curing technology. In: Proceeding fourth international conference: fly ash, silica fume, slag and natural pozzolans in concrete. Istanbul, Turkey; 1992.

[11] Swamy RN, Lambert GH. The microstructure of Lytag aggregate. Int J Cem Compos Lightw Concr 1981;3:273-82.
12] Bremner TW, Newman JB. Microstructure of low density concrete aggregate In: Proceedings 9th international conference of the FIP. Stockholm; 1982.

13] Wasserman R, Bentur A. Effect of lightweight fly ash aggregate microstructure on the strength of concretes. Cem Concr Res 1997;27:525-37.

[14] González-Corrochano B, Alonso-Azcárate J, Rodas M. Production of lightweight aggregates from mining and industrial wastes. J Environ Manage 2009;90:2801-12.

[15] Fakhfakh E, Hajjaji W, Medhioub M, Rocha F, López-Galindo A, Setti M, et al. Effects of sand addition on production of lightweight aggregates from Tunisian smectite-rich clayey rocks. Appl Clay Sci 2007;35:228-37.

[16] Riley CM. Relation of chemical properties to the bloating of clays. J Am Ceram Soc 1951;34:121-8.

17] UNE-EN 1097-6. Test for mechanical and physical properties of aggregates. Part 6: determination of particle density and water absorption; 2000.

[18] Li Y, Wu D, Zhang J, Chang L, Fang Z, Shi Y. Measurement and statistics of single pellet mechanical strength of differently shaped catalysts. Powder Technol $2000 ; 113: 176-84$

[19] UNE-EN 13055-1. Lightweight aggregates - lightweight aggregates for concrete, mortar and grout; 2003.

[20] Mehta PK, Monteiro PJM. Concrete. Microstructure, properties, and materials. 3rd ed. New York: MacGraw-Hill; 2006.

[21] Zhang $\mathrm{MH}$, Gjørv OE. Characteristics of lightweight aggregates for highstrength concrete. ACI Mater J 1991;88:150-8.

[22] Huang SC, Chang FC, Lo SL, Lee MY, Wang CF, Lin JD. Production of lightweight aggregates from mining residues, heavy metal sludge, and incinerator fly ash. J Hazard Mater 2007;144:52-8.

[23] Chiou IJ, Wang KS, Chen CH, Lin YT. Lightweight aggregate made from sewage sludge and incinerated ash. Waste Manage 2006;26:1453-61.

24] Short A. Lightweight aggregate concrete: CEB/FIP manual of design and technology. New York: Lancaster Eng. Construction Press; 1977.

[25] Soh YS, Mun KJ. Manufacturing of sintered lightweight aggregate using paper mill sludge ash (in Korean). J Korean Concr Inst 1991;13:114-9.

[26] Chen M, Ito S, Yamaguchi A. Carbonation of $\mathrm{CaO}$ clinkers and improvement of their hydration resistance. J Ceram Soc Jpn 2002;110:512-7.

27] Shi YY, Messing GL, Bradt RC. Reactive-phase calsintering of calciumcarbonate-derived lime. J Am Ceram Soc 1984;63:109-11.

[28] Aksay IA, Dabbs DM, Sarikaya M. Mullite for structural, electronic, and optical applications. J Am Ceram Soc 1991;74:2343-58.

[29] Pask JA, Tompsia AP. Formation of mullite from sol-gel mixtures and kaolinite. J Am Ceram Soc 1991;74:2367-73.

[30] Sglavo VM, Maurina S, Conci A, Salviati A, Carturan G, Cocco G. Bauxite 'red mud in the ceramic industry. Part 2: production of clay-based ceramics. J Eur Ceram Soc 2000;20:245-52.

[31] Polettini A, Pomi R, Trinci L, Muntoni A, Lo Mastro S. Engineering and environmental properties of thermally treated mixtures containing MSWI fly ash and low-cost additives. Chemosphere 2004;56:901-10.

[32] Yun YH, Yoon CH, Kim YH, Kim CK, Kim SB, Kwon JT, et al. Glass-ceramics prepared by fluorescent glass. Ceram Int 2002;28:503-5.

[33] Romero M, Rincón JM, Rawlings RD, Boccaccini AR. Use of vitrified urban incinerator waste as raw material for production of sintered glass-ceramics. Mater Res Bull 2001;36:383-95.

[34] Deer WA, Howie RA, Zussman J. An introduction to the rock-forming minerals. 2nd ed. London: Longman; 1992.

[35] déGennaro $R$, Dondi M, Cappelletti $P$, Colella A, Langella A. Use of high-grade zeolite-bearing rocks as raw material for the preparation of lightweight aggregates. In: Proc EUROMAT, AIM (Ass. Ital. Metallurgia). Milan (Abstract in "Conference Abstracts", p. 354); 2001.

[36] Decleer J, Viaene W. Rupelian Boom clay as raw material for expanded clay manufacturing. Appl Clay Sci 1993;8:111-28.

[37] Lin KL. Mineralogy and microstructures of sintered swage sludge ash as lightweight aggregates. J Ind Eng Chem 2006;12:425-9. 